\title{
MELATIH KECERDASAN MATEMATIS LOGIS ANAK MELALUI KEGIATAN FUN COOKING DI SD NU METRO LAMPUNG
}

\author{
Masrurotul Mahmudah, Nur Laili, Muh. Ngali Zainal \\ Makmun
}

\author{
Prodi Pendidikan Guru Madrasah Ibtidaiyah, Fakultas Tarbiyah \\ IAIMNU Metro Lampung \\ mahmudahmasrurotul1@gmail.com, Nurlailimz89@gmail.com, \\ zainalmakmun@gmail.com
}

\begin{abstract}
Abstrak
Penelitian ini dilatarbelakangi oleh rasa keingintahuan dalam hal pengembangan kecerdasan matematis logis pada anak di SD NU Metro Lampung siswa kelas I. Penelitian ini fokus pada kegiatan fun cooking yang mana kegiatan itu bertujuan untuk mengembangkan minat dan bakat anak. Penelitian ini menggunakan metode analisis kritis, sehingga kajian ini bersifat deskriptif analitis kualitatif guna menjadi sebuah inovasi pembelajaran dalam pengembangan kecerdasan matematis Anak. Dari hasil penelitian dapat diketahui bahwa para siswa- siswi kelas I di SD NU sangat antusias dalam mengikuti kegiatan fun cooking. Melalui beberapa proses, tahapan dan penjelasan yang di sampaikan oleh guru, ternyata pengembangan kecerdasan matematis logis anak, pada siswa-siswi kelas I sangat efisien dan dapat dilihat bahwa anak mampu memahami bermacam-macam jenis bahan makanan pokok, takaran-takaran dalam membuat adonan, anak mampu memahami angka-angka, memahami durasi waktu untuk memanggang kue, kreatif dalam mencetak dan membuat inovasi pada pizza, memahami bangun ruang, misal bulat, persegi, segi tiga, dan lain sebagainya.
\end{abstract}

Kata kunci: Fun Cooking, Kecerdasan Matematika, Minat dan Bakat

\begin{abstract}
This research was motivated by curiosity in terms of developing logical mathematical intelligence in first grade students at SD NU Metro Lampung. This research focused on Fun Cooking activities which aim to develop children's interests and talents. This study uses critical analysis method, so this study is descriptive qualitative analysis to become a learning innovation in students development at mathematical intelligence. From the results of the study, it can be seen that the first grade students at SD NU are very enthusiastic in participating in Fun Cooking activities. Through several processes, stages and explanations conveyed by the teacher, it turns out that the development of children's logical mathematical intelligence, in first grade students is very efficient and it can be seen that children are able to understand various types of staple food ingredients, dosages in making dough, children are able to understand numbers, understand the duration of time to bake cakes, be creative in printing and make innovations on pizza, understand geometric shapes, for example round, square, triangle, and so on.
\end{abstract}

Keywords: Fun Cooking, Mathematical Intelligence, Interests and Talents 


\section{A. Pendahuluan}

Pendidikan merupakan usaha sadar dan terencana yang dilakukan seseorang dalam mengembangkan potensi dirinya agar bermanfaat bagi kepentingan hidupnya. Menurut Nuarini Soyomukti, pendidikan adalah proses untuk memberikan manusia berbagai macam situasi yang bertujuan sebagai pemberdayaan diri. ${ }^{1}$ Berdasarkan Undang-Undang Sisdiknas No.20 Tahun 2003 Bab I Pasal I dalam Akhmad Muhaimin Azzet menjelaskan bahwa pendidikan adalah usaha sadar dan terencana untuk mewujudkan suasana belajar dan proses pembelajaran agar peserta didik secara aktif mengembangkan potensi dirinya untuk memiliki kekuatan spiritual keagamaan, pengendalian diri, kepribadian, akhlak mulia, serta keterampilan yang diperlukan dirinya, masyarakat maupun bangsa dan Negara. ${ }^{2}$

Pada saat ini perkembangan pendidikan menghadapi dua tantangan eksternal, yaitu pertama krisis etika dan moral anak bangsa, dan kedua tantangan masyarakat global. Etika dan tata krama bangsa yang selama ini dijunjung tinggi berubah menjadi budaya anarkis, kekerasan, tawuran, amoral, asusila dan tidak peduli dengan sesama. Maka diperlukan adanya formulasi tentang sistem pendidikan yang komprehensif, integratif, seimbang, dan terpadu, atas dasar prinsip kesatuan ilmu pengetahuan dan ilmu agama, antara kepentingan dunia dan akhirat, material dan spiritual, jasmaniyah dan rohaniyah.

Hubungan antara pendidikan dan masyarakat tidak bersifat linear, melainkan hubungan timbal balik (simbiosis mutualis). Perubahan pada masyarakat akan membawa perubahan dalam pendidikan, begitu sebaliknya, perubahan dalam pendidikan akan membawa perubahan pada masyarakat. Keberadaan dan jenjang pendidikan sekolah dasar adalah awal dari segala pondasi keilmuan yang akan membekali potensi bangsa Indonesia secara holistik. Oleh karena itu, dasar dari sebuah pengembangan keilmuan sangat membutuhkan kredibilitas, profesionalitas dan akuntabilitas seorang pendidik yang mampu menerima segala macam perbedaan potensi dan karakter peserta didik. Pendidikan karakter ini menjadi titik tekan penting dalam pendidikan di Indonesia. Character according to language

\footnotetext{
${ }^{1}$ Nurani Soyomukti, Teori-Teori Pendidikan, Yogyakarta: Ar-Ruzz Media, 2015, hlm.3.

${ }^{2}$ Akhmad Muhaimin Azzet, Pendidikan Yang Membebaskan, Yogyakarta: Ar-Ruzz Media, 2011, hlm. 12 .
} 
means habit, whereas according to terms, character is a system of beliefs and habits that direct the actions of an individual. ${ }^{3}$ Dengan demikian karakter menjadi salah satu tujuan yang harus dapat dibentuk melalui proses pendidikan dalam keluarga maupun pendidikan sekolah.

Kemampuan yang dimiliki oleh pendidik itu sangat berpengaruh pada pola pengembangan kecerdasan dan potensi anak. Dalam mengembangkan kecerdasan anak membutuhkan banyak strategi, metode dan media-media pembelajaran. Banyak orang tua yang kurang paham tentang kecerdasan yang dimiliki oleh anaknya sendiri, sehingga yang sering terjadi adalah orang tua hanya menuntut anaknya untuk bisa menjadi sesosok manusia yang dapat mengikuti segala perintah, cita-cita dan harapan orang tua. Akan tetapi para orang tua tersebut tidak pernah peduli dengan kecerdasan apa yang sebenarnya dimiliki oleh anaknya sendiri.

Pendidikan anak tidak hanya mengembnagkan yang bersifat fisik, lebih utama justru pada pengembangan emosional, intelektual, dan sosial anak di lingkungan keluarga. ${ }^{4}$ Pendidikan anak usia dini memiliki peran yang sangat menentukan keberhasilan pada pendidikan jenjang berikutnya. Pada usia ini berbagai pertumbuhan dan perkembangan mulai dan sedang berlangsung, seperti perkembangan fisiologis, bahasa, motorik, kognitif maupun afektif. Perkembangan ini akan menjadi dasar bagi perkembangan anak selanjutnya.

Tujuan pendidikan adalah menciptakan seseorang yang berkualitas dan berkarakter sehingga memiliki pandangan yang luas ke depan untuk mencapai suatu cita-cita yang diharapkan dan mampu beradaptasi secara cepat dan tepat di dalam berbagai lingkungan. Karena pendidikan itu sendiri memotivasi diri kita untuk lebih baik dalam segala aspek kehidupan.

Menurut Gordon dan Browne dalam Susanto bahwa kreativitas merupakan kemampuan untuk menciptakan gagasan baru yang imajinatif dan juga kemampuan mengadaptasi gagasan baru dengan gagasan yang sudah ada. Dalam pandangan Gorden, kreativitas-inovasi gagasan yang sudah ada menjadi lebih inovatif dan

${ }^{3}$ Fitria Martanti, Integration Of Aswaja Teaching: Concpept Of Strengthening Character EducationinCollege,JurnalTawasutVolume7Nomer1,2020, <https://www.publikasiilmiah.unwahas.ac.id/in dex.php/TWS/article/view/3436\%0>.

${ }^{4}$ Rosyadi Rahmat, Pendidikan Islam Dalam Pembentukan Karakter Anak Usia Dini, Jakarta: Rajawali Pers, 2013, hlm.7. 
imajinatif. ${ }^{5}$ Menurut Munandar kreativitas adalah kemampuan seseorang untuk melahirkan sesuatu yang telah ada sebelumnya. ${ }^{6}$

Menurut Suratno kegiatan pengembangan kreativitas anak yaitu bermain kreatif aktif dan pasif. Kegiatan bermain kreatif aktif meliputi bermain bebas, bermain konstruktif, bermain peran, eksplorasi, bermain musik, dan mengumpulkan benda. Sedangkan kegiatan bermain kreatif pasif meliputi mendengar, melihat komik atau majalah, menonton TV dan film, serta aktivitas mendengarkan musik. Bermain merupakan kegiatan yang serius tetapi mengasyikkan sekaligus bagi anak.

Permainan adalah alat bagi anak untuk menjelajah dunia bermainnya. Harun Rasyid juga menjelaskan bahwa inti bermain bagi anak usia dini yaitu menyenangkan, bergembira, rileks, sukacita, mendidik, serta dapat menumbuhkan aktivitas dan kreativitas. Berdasarkan paparan di atas dapat dipahami bahwa bermain sangat dibutuhkan oleh anak. Dengan esensi bahwa kegiatan bermain yang sangat penting bagi anak maka bermain dapat dijadikan sebagai sarana untuk mengembangkan segala aspek perkembangan anak secara optimal. Bermain sebagai sarana pengembangan aspek dirancang menjadi metode bermain sambil belajar. Pembelajaran dengan konsep bermain sambil belajar adalah permainan yang sesuai dengan anak.

Melalui bermain yang efektif terjadi sebuah proses anak akan mendapatkan pengalaman, pengetahuan, dan pemecahan masalah yang konstruk oleh dirinya sendiri. Bermain kreatif dapat dilakukan dengan merancang kegiatan bermain sedemikian rupa sehingga dapat meningkatkan bidang kreativitas dan bidang lain untuk menjadi pembelajaran yang terpadu. ${ }^{7}$

Mengingat bahwa pada usia dini bermain merupakan dunia anak. Memilih permainan yang tepat untuk mengembangkan kreativitas anak juga sangatlah penting. Bermain fun cooking merupakan salah satu alternatif yang dapat dipilih dalam pembelajaran. Bermain fun cooking untuk anak usia dini disesuaikan dengan prinsip pembelajaran anak usia dini yaitu berpusat pada anak dan menyenangkan. Menurut Setyawati melalui bermain fun cooking anak disuguhkan dengan media

\footnotetext{
${ }^{5}$ Ahmad Susanto, Perkembangan Anak Usia Dini, Jakarta: Prenadamedia, 2011, hlm.15.

${ }^{6}$ Utami Munandar, Pengembangan Kreativitas Anak Berbakat, Jakarta: Rineka Cipta, 2012, hlm.5.

${ }^{7}$ Dina Setyawari, Upaya Mengembangkan Kreativtas Anak Melalui Fun Cooking Di Kelompok B TK Puspitasari, Pengasih, Kulon Progo," n.d., 2. hlm.20.
} 
belajar berupa bahan makanan yang akan diolah menjadi makanan yang telah disediakan sesuai dengan ide dan gagasannya. ${ }^{8}$

Menurut Rachmawati dan Kurniati aktivitas bermain fun cooking merupakan salah satu strategi dalam mengembangkan kreativitas melalui hasta karya atau penciptaan produk. Melalui aktivitas bermain fun cooking anak akan beraktivitas membuat, menyusun, atau mengkontruksikan bahan sesuai dengan khayalan dan imajinasinya. Dalam pembuatan hasta karya setiap anak menggunakan imajinasinya untuk membentuk sesuatu dengan khayalannya. Setiap anak bebas mengekspresikan kreativitasnya, sehingga akan diperoleh hasil yang beda antara satu anak dengan yang lainnya. ${ }^{9}$

Bermain fun cooking diharapkan dapat meningkatkan kreativitas anak dan mampu mengembangkan minat dan bakat anak karena bermain fun cooking dengan anak-anak dapat memberikan pengalaman belajar anak. Pengalaman yang didapat berupa pengalaman bidang matematika, keterampilan bahasa, sains, keterampilan motorik, kreativitas, serta emosi dan perkembangan sosial.

Hal ini yang menjadi dasar keberadaan SD NU Kota Metro mempunyai program-program unggulan yang diwujudkan dengan berbagai kegiatan yang mendukung pengembangan kecerdasan-kecerdasan para peserta didik. Programprogram itu dibuat untuk memberikan penyadaran untuk para orang tua dan para peserta didik semuanya. Selain itu, dengan program-program unggulan dan kegiatan-kegiatan yang ada merupakan sebuah inovasi pembelajaran yang menyenangkan tanpa memberikan beban kepada peserta didik.

\section{B. Metode Penelitian}

Penelitian ini menggunakan metode kualitatif. Penelitian kualitatif merupakan metode penelitian naturalistik karena penelitiannya dilakukan pada kondisi sebenarnya. ${ }^{10}$ Penelitian kualitatif dilakukan dengan membuat deskripsi, gambaran sistematis, faktual dan akurat mengenai fakta-fakta, sifat-sifat serta

\footnotetext{
${ }^{8}$ Arinal Hasanah Putri Fatmawati, Perkembangan Kreativitas Melalui Bermain Fun Cooking, FKIP Universitas Lampung, n.d. hlm.17.

${ }_{9}^{9}$ Yeni Rachmawati, Srategi Pengembangan Kreativitas Pada Anak, Jakarta: Kencana Prenada Media Group, 2010, hlm.21.

${ }^{10}$ Fitria Martanti, Peran Guru Kelas Dalam Memberikan Layanan Bimbingan Konseling di SDN Watuaji01KabupatenJepara,Magistra,6(2015), <https://publikasiilmiah.unwahas.ac.id/index.php/MAGIS TRA/article/view/1776\%0D>. hlm 27
} 
hubungan antara berbagai fenomena yang diteliti secara mendalam. ${ }^{11}$ sehingga kajian ini bersifat deskriptif analitis kualitatif yang mendeskripsikan secara mendalam terkait pembelajaran dalam pengembangan kecerdasan matematis anak. Teknik pengumpulan data yang digunakan adalah wawancara, observasi non partisipan, dan dokumentasi. Dalam pengumpulan data terkait wawancara ada beberapa pihak yang peneliti wawancarai diantaranya yaitu informan 1 (guru kelas A), informan 2 (guru kelas B), informan 3 (guru pendamping), dan informan 4 (kepala sekolah). Dengan melakukan wawancara, dokumentasi dan observasi diperoleh data yang lengkap berkaitan dengan kegiatan fun cooking dalam mengembangkan kecerdasan matematis logis di lokasi penelitian.

\section{Hasil dan Pembahasan}

Pada saat ini perkembangan pendidikan menghadapi dua tantangan eksternal, yaitu pertama kritis etika dan moral anak bangsa, dan kedua tantangan masyarakat global. Etika dan tata krama bangsa yang selama ini di junjung tinggi berubah menjadi budaya anarkis, kekerasan, tawuran, amoral, asusila dan tidak peduli dengan sesama. Maka diperlukan adanya formulasi tentang sistem pendidikan yang komprehensif, integratif, seimbang, dan terpadu, atas dasar prinsip kesatuan ilmu pengetahuan dan ilmu agama, antara kepentingan dunia dan akhirat, material dan spiritual, jasmaniyah dan rohaniyah.

Merujuk pada tujuan pendidikan holistik yang berbasis karakter dalam membentuk manusia yang utuh (whole person) yang cakap dalam menghadapi berbagai tantangan kehidupan, serta memiliki kesadaran spiritual bahwa dirinya merupakan bagian dari keseluruhan (the person within a whole). Beberapa aspek yang harus terpenuhi sebagai manusia yang holistik ialah: Aspek fisik, aspek emosi, aspek sosial dan budaya, aspek kreativitas, aspek spiritual, dan aspek akademik.

Selain itu, jika merujuk pada teori Howard Gardner yang menyebutkan bahwa kecerdasan matematis adalah adanya kemampuan berhitung yang sangat cepat meskipun mereka ada kekurangan dalam sebagian besar bidang lain. Oleh karena itu sebagai guru harus bersikap adil dan bijaksana dalam menyajikan modelmodel pembelajaran. Melihat kondisi tidak semua anak dapat memahami materi berhitung dengan proses yang sama atau bahkan dengan proses yang singkat,

${ }^{11}$ Fitria Martanti, Metode Struktural Analitik Sintetik dalam Pembelajaran Anak Dislikesia.AlBidayah,vol.10 No.1, 2018, hlm.23 
namun demi untuk membantu mengembangkan kecerdasan matematis logis pada anak semua pihak baik guru, program sekolah dan seluruh anak bisa mendapatkan kualitas pembelajaran yang baik.

Salah satu kegiatan ekstrakurikuler di SD NU adalah fun cooking, kegiatan itu dilakukan bukan karena sebatas kegiatan pelengkap atau ramai-ramai untuk anak. Akan tetapi mempunyai tujuan tersendiri yaitu mengembangkan kecerdasan matematis pada anak dengan konsep belajar sambil berkarya. Adapun yang dimaksud dengan belajar sambil berkarya adalah anak harus mendengarkan penjelasan guru, memahami perintah guru dan sekaligus perperan langsung dalam membuat olahan makanan. Pada akhirnya para siswa tersebut dapat mengetahui macam-macam jenis bahan-bahan makanan pokok yang dibutuhkan. Mengetahui cara membuat adonan beserta takarannya, dan dapat mengikuti proses pembuatan olah makanan dengan mengerjakan sendiri sebagaimana yang ditugaskan oleh para guru.

Salah satu bidang pengembangan yang diajarkan di SD NU Metro adalah kreativitas dan minat serta bakat peserta didik yang termasuk dalam kegiatan terpadu yang mengembangkan seluruh aspek perkembangan terutama aspek kognitif dan seni. Pendidik berusaha memeberikan pelayanan pengembangan kreativitas dengan melakukan kegiatan menggambar bebas, mewarnai, dan bermain membentuk plastisin serta pembelajaran fun cooking.

Fun cooking untuk anak-anak disesuaikan dengan prinsip pembelajaran anak yaitu berpusat pada anak yang menyenangkan. Anak disuguhkan dengan sumber belajar berupa bahan makanan yang akan diolah menjadi makanan yang siap disajikan. Anak-anak akan bereksplorasi dengan bahan amakanan yang telah disediakan sesuai dengan ide dan gagasannya. Fun cooking termasuk dalam bermain asosiatif dan bermain bersama atau kooperatif serta dapat meningkatkan kemampuan matematis logis.

Bermain asosiatif fun cooking yaitu ketika anak bermain mengolah makanan secara individual, yakni anak akan bekerja sendiri tanpa campur tangan orang lain tetapi masih saling tukar menukar alat bermain dengan orang lain. Tujuan dari bermain asosiatif yaitu mengembangkan anak sesuai dengan gagasannya sendiri dan sarana mengekspresikan ide anak secara natural tanpa 
pengaruh dari orang lain. Bermain kooperatis fun cooking terlihat ketika anak berasama-sama dengan anak yang lain mengerjakan satu proyek dan hasil proyek tersebut merupakan hasil ide pemikiran semua anak. Sedangkan kemampuan matematis logis ketika anak mulai menakar bahan makanan.

Fun cooking mempunyai kelebihan yaitu dapat meningkatkan kreativitas anak, dapat mengenalkan alat dan bahan memasak, mengenalkan teknik memasak, dan memberikan pengalaman sains berupa perubahan bahan makanan mentah menjadi siap saji. Bermain fun cooking dapat memasukkan kegiatan menggambar dan membentuk dengan menggunakan bahan makanan. Dengan kegiatan yang baru anak lebih antusias dalam mengembangkan aspek kreativitasnya.

Dari hasil kegiatan fun cooking tersebut guru dan para siswa merasa ada aura positif dan ada dampak yang sangat signifikan dalam pengembangan kecerdasan matematis logis pada anak. Kegiatan ini akan terus dilakukan oleh guru guna mendukung minat bakat para siswa dan mendukung pengembangan potensipotensi yang lain, misal kecerdasan matematis logis, linguistik, interpersonal, intrapersonal, dan kognitif. Bahkan dalam penekanan pendidikan karakter pada aspek sosial dan budaya.

Selain itu, Penekanan pada aspek akademik diantaranya yaitu: berfikir logis, berbahasa dan menulis dengan baik, dapat mengemukakan pertanyaan kritis dan mampu menarik simpulan dari berbagai informasi yang diketahui, hal ini ditunjukkan pada respon siswa dalam mengikuti perintah guru, memahami penjelasan guru dan berani bertanya ketika siswa belum paham. Sehingga tercipta situasi pembelajaran yang terbuka dan berkarakter sesuai muatan materi pembelajaran.

Kegiatan fun cooking merupakan salah satu kegiatan yang ditunggu-tunggu peserta didik SD NU Kota Metro lantaran pelaksanaannya yang hanya satu kali dalam satu semester. Dalam kegiatan tersebut para peserta didik sangat senang, mereka terlihat seperti bermain padahal banyak pelajaran yang telah mereka lewati. Para orang tuapun antusias dalam mendukung terlaksananya program tersebut, dengan dibuktikan setiap ada bahan atau peralatan yang harus dibawa oleh anak, maka orang tua juga menyiapkan untuk anak-anaknya. Pentingnya melibatkan anak dalam kegiatan masak-memasak atau membuat makanan ringan sangatlah 
penting, karena banyak pelajaran yang dapat dipetik seperti menanamkan kesabaran, kedisiplinan, ketelitian dan yang lebih penting membangun kedekatan emosional kepada anak.

Program fun cooking ini merupakan program yang sangat berpengaruh dalam mendobrak motivasi belajar anak dalam menyenangi pelajaran matematika atau berhitung. Selama ini materi yang berkaitan hitungan dan analisis cerita masih banyak dikesampingkan oleh anak-anak karena dianggap materi yang sangat sulit dan membutuhkan titik fokus yang tinggi. Dengan adanya kegiatan fun cooking ini anak-anak tidak lagi merasa takut dan pusing ketika dihadapkan dengan materi berhitung dan analisis cerita, itu dikarenakan suasana pembelajarannya menyenangkan dan santai tapi serius dan hasilnyapun terlihat efisien. Dimana dalam proses kegitan itu seluruh anak antusias dengan tugasnya masing dan saling bekerjasama dengan kelompoknya. Dalam kegiatan ini memuat aspek kreativitas diantaranya yaitu: mampu mengekspresikan diri dalam berbagai kegiatan produktif serta mampu mencari solusi tepat dari berbagai masalah dengan sistem kerjasama dan musyawarah.

Kecerdasan matematis-logis merupakan kombinasi dari kemampuan anak dalam berhitung dan kemampua anak dalam logika sehingga siswa dapat menyelesaikan suatu masalah secara logis. Siswa yang memiliki kecerdasan matematis logis yang tinggi cenderung dapat memahami suatu masalah dan menganalisa serta menyelesaikannya dengan tepat. Demikian pula dalam kegiatan belajar matematika, siswa yang memiliki kecerdasan matematis-logis tinggi sehingga hasil belajarnya pun tinggi. Akan tetapi, pada kenyataannya masih banyak siswa yang kemampuan dalam berhitung dan logikanya masih kurang baik. Masalah ini dapat dilihat ketika siswa diberikan soal-soal cerita yang perlu dianalisis terlebih dahulu. Mereka tidak dapat menjawab soal-soal tersebut dikarenakan mereka tidak dapat mengidentifikasi dan menganalisis masalahmasalah dalam soal tersebut.

Dalam buku Gardner menyebutkan bahwa kecerdasan matematis adalah adanya kemampuan berhitung yang sangat cepat meskipun mereka ada kekurangan dalam sebagian besar bidang lain. ${ }^{12}$ Dalam penelitian Suhendri yang berjudul

\footnotetext{
${ }^{12}$ Howard Gardner, Multiple Intelegences, Kecerdasan Majemuk Teori Dan Praktek, Batam:
} 
Pengaruh Kecerdasan Matematis Logis dan Kemandirian Belajar Terhadap Hasil Belajar Matematika Program Studi Pendidikan Matematika, Universitas Indraprasta PGRI (UNINDRA), Tanjung Barat, Jagakarsa, Jakarta Selatan mengutip beberapa teori diantaranya yaitu: Menurut Gagne yang dikutip oleh Abdul Rahman Shaleh bahwa: "Belajar terjadi apabila suatu situasi stimulus bersama-sama dengan isi ingatan mempengaruhi siswa sedemikian rupa sehingga perbuatannya (performance-nya) berubah dari waktu sebelum ia mengalami situasi itu ke waktu sesudah ia mengalami situasi tadi."13

Menurut Hilgrad dan Brower yang dikutip oleh Abdul Rahman Shaleh bahwa:"Belajar berhubungan dengan perubahan tingkah laku seseorang terhadap suatu situasi tertentu yang disebabkan oleh pengalamannya secara berulang-ulang dalam situasi itu, di mana perubahan tingkah laku itu tidak dapat dijelaskan atau dasar kecenderungan respon pembawaan, kematangan, atau keadaan-keadaan sesaat seseorang (misalnya: kelelahan, pengaruh obat, dan sebagainya)."14

Kecerdasan matematis-logis melibatkan banyak komponen: perhitungan secara matematis, berpikir logis, pemecahan masalah, pertimbangan deduktif dan induktif, dan ketajaman pola-pola dan hubungan-hubungan. Dalam hal ini ada pendapat lain seperti yan penulis kutip dari penelitian In'am mengatakan bahwa pembelajaran matematika yang memudahkan peserta didik agar memahami materi yang dipelajari melalui kemampuannya sendiri dapat dilakukan melalui proses internalisasi, sehingga konsep yang dipelajari dapat terbangun dan transformasi informasi yang diperoleh menjadi konsep baru. ${ }^{15}$

Pembelajaran matematika sudah seharusnya dirancang untuk membantu peserta didik mudah dalam memahami materi yang sedang dipelajari, sehingga peran guru terhadap peserta didik dalam inovasi pembelajaran matematika di kelas perlu diperhatikan. Oleh karena itu, aktivitas yang dilaksanakan guru pada kegiatan pembelajaran, baik merancang pembelajaran, pelaksanaan pembelajaran, melaksanakan rancangan maupun melakukan evaluasi adalah sangat berpengaruh

\footnotetext{
Interaksa, 2008, hlm.32.

${ }^{13}$ Huri Suhendri, Kecerdasan Matematis Logis Dan Kemandirian Belajar Terhadap Hasil Belajar Matematika, 2008. hlm.13.

${ }^{14}$ Rahman Abdul Shaleh, Psikologi (Suatu Pengantar Dalam Perspektif Islam), Jakarta: Prenada Media Group, 2009, hlm.24.

${ }^{15}$ Akhsanul In'am, Efektivitas Model Pembelajaran Matematika Berbasis Metakognitif, 2009.hlm.30.
} 
terhadap pencapaian prestasi peserta didik.

Menurut Saifullah bahwa kecerdasan matematis-logis adalah kemampuan menggunakan angka dengan baik dan melakukan penalaran yang benar. Kecerdasan ini meliputi kepekaan pada pola dan hubungan logis, pernyataan dan dalil (jikamaka, sebab-akibat) fungsi logis dan abstraksi-abstraksi lainnya. ${ }^{16}$ Proses yang digunakan dalam kecerdasan logis matematis ini antara lain: kategorisasi, klasifikasi, pengambilan simpulan, generalisasi, perhitungan, dan pengajuan hipotesis. Menurut May bahwa kecerdasan matematis-logis adalah kemampuan untuk menangani bilangan dan perhitungan, pola dan pemikiran logis dan ilmiah. ${ }^{17}$ Menurut Budiningsih bahwa kecerdasan logika/matematik sering disebut berpikir ilmiah, termasuk berpikir deduktif dan induktif. Menurut pendapat ini bahwa kecerdasan matematis-logis merupakan proses berpikir ilmiah dalam menyelesaikan suatu masalah dengan berdasarkan pada kebenaran logika. ${ }^{18}$

Dalam kegiatan pembelajaran khususnya pelajaran matematika diupayakan menggunakan metode pembelajaran yang dapat menumbuhkan atau meningkatkan kecerdasan matematis-logis. Menurut Saifullah menyataakan bahwa ada 4 (empat) bentuk metode belajar matematika yang dapat meningkatkan kecerdasan matematis-logis, yaitu: metode eksperimen, metode tanya jawab, dan metode latihan soal-soal berhitung. ${ }^{19}$

Dari beberapa teori yang telah diuraikan di atas dapat dipahami bahwa kecerdasam matematis logis adalah sebuah kecerdasan yang dapat memahami dan menghitung soal matematik dengan disajikan secara penalaran dan analisis kritis yang ditunagkan dalam bentuk cerita. Dengan demikian ketika seorang guru mempunyai inovasi pembelajaran yang dapat menjadi strategi untuk memudahkan anak dalam memahami materi pelajaran yang disampaikan oleh guru. Dalam hal ini guru di SD NU mengembangkan proses pembelajaran dengan melakukan program fun cooking yang sudah terprogram dan terjadwal. Adapun pelaksanaan kegiatan fun cooking tersebut sehari full, dengan tujuan totalitas dalam pelaksanaannya.

\footnotetext{
${ }^{16}$ Syaifullah, Mencerdaskan Anak (Mengoptimalkan Kecerdasan Intelektual, Emosi Dan Spiritual Anak), Jombang: Lintas Media, 2004, hlm.11.

${ }^{17}$ May L win, How to Multiply Your Child's Intelligence, Yogyakarta: Indeks, 2008, hlm.37.

${ }^{18}$ C. Asri Budiningsih, Belajar Dan Pembelajaran, Jakarta: PT. Rineka Cipta, 2005, hlm.29.

${ }^{19}$ Syaifullah, Mencerdaskan Anak (Mengoptimalkan Kecerdasan Intelektual, Emosi Dan Spiritual Anak) hlm.11.
} 
Sehingga ahir dari kegiatan tersebut terlihat perubahan yang dimiliki anak didik.

\section{Simpulan}

Dari analisis kritis tentang Pengembangan Kecerdasan Matematis Logis Anak Melalui Kegiatan Fun Cooking di SD NU Metro Lampung yang merujuk

Page|56 pada basis pembelajaran yang dimiliki yaitu religius, joyfull, challenging, meaningfull, and Personal system of intruction. Maka kegitan Fun Cooking ini termasuk pada basis Joyfull learning: Pembelajaran menyenangkan, pendekatan yang diinginkan oleh pengajar (guru) untuk membuat siswa lebih dapat menerima materi yang disampaikan yang dikarenakan suasana yang menyenangkan dan tanpa ketegangan dalam menciptakan rasa senang. Pembelajaran yang menyenangkan bukan semata-semata pembelajaran yang mengharuskan anak-anak untuk tertawa terbahak-bahak, melainkan sebuah pembelajaran yang di dalamnya terdapat pondasi yang kuat antara guru dan peserta didik dalam suasana yang sama sekali tidak ada tekanan yang ada hanyalah jalinan komunikasi yang saling mendukung. Basis challenging learnig yang terjadi merupakan sebuah proses pembelajaran yang menantang dan dilakukan oleh guru yang kreatif, aktif berinovatif yang bisa menyampaikan suatu materi dengan baik kepada peserta didik sehingga peserta didik bisa merasakan adanya tantangan belajar yang menyenangkan. Suatu pembelajaran yang menantang tidak hanya dilakukan di dalam kelas tapi juga di luar kelas.

Dapat dilihat dan dirasakan perubahannya yang positif yaitu antusias anak dalam proses belajar sangat tinggi, motivasi belajar yang besar, kekompakan dan kebersamaan yang bagus, tanggung jawab yang baik, mampu memahami berbagai jenis bahan pokok dan takaran yang harus disesuaikan dengan perintah guru, mandiri dalam mengolah pizza, memahami durasi waktu pemanggangan pizza, dapat memotong adil pizza hasil buatan bersama sesuai dengan jumlah kelompok. Selain itu anak mempunyai kenyamanan dalam belajar dan berkarya. Adapun kecerdasan matematis logis pada anak yang berkembang adalah dapat memahami angka-angka dengan cepat karena ada tugas membuat takaran, adonan dan durasi memanggang kue, selain itu anak-anak dapat memahami alur pembuatan pizza dengan memperhatikan penjelasan guru dan mereka terapkan secara seksama agar tidak terjadi kesalahan dalam pemilihan bahan, penakaran adonan dan memahami waktu pemanggangan. Dengan kegiatan yang menyenangkan tidak menegangkan 
anak antusias dalam memahami materi-meteri yang disampaikan guru. Selain itu, guru dan siswa merasakan ada aura positif dan ada dampak yang sangat signifikan dalam pengembangan kecerdasan matematis logis pada anak. Kegiatan ini akan terus dilakukan oleh guru guna mendukung minat bakat para siswa dan mendukung pengembangan potensi-potensi yang lain, misalnya kecerdasan matematika logis, linguistik, interpersonal, intrapersonal, dan kognitif. Selain itu kegiatan fun cooking juga dapat membentuk pendidikan karakter pada aspek sosial dan budaya yang ditekankan pada diantaranya: belajar menyenangi pekerjaanya, bekerja dalam tim, pandai bergaul, kepedulian masalah sosial dan berjiwa sosial, bertanggung jawab, menghormati orang lain, mengerti perbedaan antara budaya dan kebiasaan orang lain, dan mematuhi segala peraturan yang berlaku.

Penekanan pada aspek akademik diantaranya yaitu: berpikir logis, berbahasa dan menulis dengan baik, dapat mengemukakan pertanyaan kritis dan mampu menarik simpulan dari berbagai informasi yang diketahui, hal ini ditunjukkan pada respon siswa dalam mengikuti perintah guru, memahami penjelasan guru dan berani bertanya ketika siswa belum paham. Pada akhirnya tercipta situasi pembelajran yang terbuka dan berkarakter sesuai muatan materi pembelajaran.

\section{DAFTAR PUSTAKA}

Azzet, Akhmad Muhaimin. Pendidikan Yang Membebaskan. Yogyakarta: Ar-Ruzz Media, 2011.

Budiningsih, C. Asri. Belajar Dan Pembelajaran. Jakarta: PT. Rineka Cipta, 2005.

Gardner, Howard. Multiple Intelegences (Kecerdasan Majemuk Teori Dan Praktek). Batam: Interaksa, 2008.

In’am, Akhsanul. “'Efektivitas Model Pembelajaran Matematika Berbasis Metakognitif,", 2009.

L win, May. How to Multiply Your Child's Intelligence. Yogyakarta: Indeks, 2008.

Martanti, Fitria, Peran Guru Kelas Dalam Memberikan Layanan Bimbingan Konseling diSDNWatuaji01KabupatenJepara,Magistra,6(2015), <https://publikasiilmiah.un 
wahas.ac.id/index.php/MAGISTRA/article/view/1776\%0D>.

Martanti, Fitria, Metode Struktural Analitik Sintetik dalam Pembelajaran Anak Dislikesia.Al-Bidayah,vol.10 No.1, 2018.

Page $\mid 58$

Martanti, Fitria, Integration Of Aswaja Teaching: Concpept Of Strengthening Character EducationinCollege,JurnalTawasutVolume7Nomer1,<https://www.publikasiilmi ah.unwahas.ac.id/index.php/TWS/article/view/3436\%0>.

Munandar, Utami. Pengembangan Kreativitas Anak Berbakat. Jakarta: Rineka Cipta, 2012.

Putri Fatmawati, Arinal Hasanah. Perkembangan Kreativitas Melalui Bermain Fun Cooking. FKIP Universitas Lampung, n.d.

Rachmawati, Yeni. Srategi Pengembangan Kreativitas Pada Anak. Jakarta: Kencana Prenada Media Group, 2010.

Rahmat, Rosyadi. Pendidikan Islam Dalam Pembentukan Karakter Anak Usia Dini. Jakarta: Rajawali Pers, 2013.

Setyawari, Dina. "Upaya Mengembangkan Kreativtas Anak Melalui Fun Cooking Di Kelompok B TK Puspitasari, Pengasih, Kulon Progo,” n.d., 2.

Shaleh, Rahman Abdul. Psikologi (Suatu Pengantar Dalam Perspektif Islam). Jakarta: Prenada Media Group, 2009.

Soyomukti, Nurani. Teori-Teori Pendidikan. Yogyakarta: Ar-Ruzz Media, 2015.

Suhendri, Huri. "Kecerdasan Matematis Logis Dan Kemandirian Belajar Terhadap Hasil Belajar Matematika,” 2008.

Susanto, Ahmad. Perkembangan Anak Usia Dini. Jakarta: Prenadamedia, 2011. Syaifullah. Mencerdaskan Anak (Mengoptimalkan Kecerdasan Intelektual, Emosi Dan Spiritual Anak). Jombang: Lintas Media, 2004. 